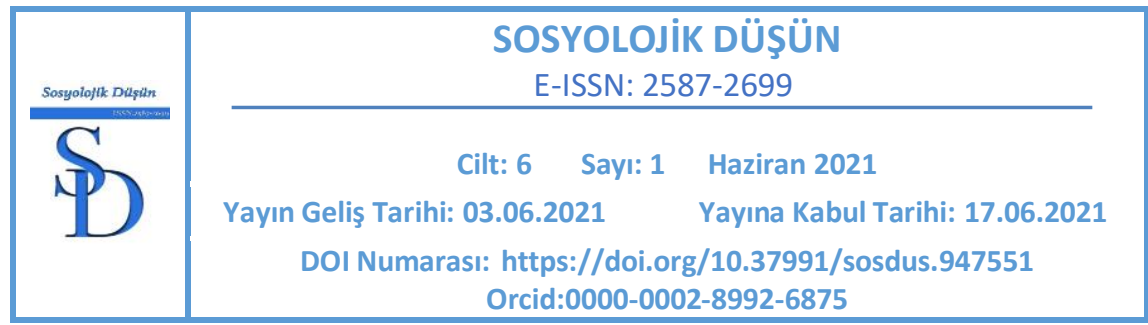

\title{
THE EFFECT OF RELIGIOUS FACTORS ON TRADITIONAL GENDER BELIEFS IN TURKEY
}

\begin{abstract}
Ahmet FiDAN*
Abstract

The main purpose of the present study is to examine the relationship between religiosity and gender traditionalism in a secular and Muslim country, Turkey. Based on previous research and perspectives several hypotheses were developed to test. A joint data, which is collected by European Value Survey and World Value Survey from Turkey in 2018, was used for analysis. A series of models of linear logistic regression was created to test the effect of each predictor variable on traditional gender beliefs. The results indicated that subjective religiosity and given importance to religion were strongly, significantly, and positively associated with gender traditionalism while prayer practice showed a slight and positive effect on gender traditionalism. Implications of the study were discussed and concluded, limitations were identified for future work.
\end{abstract}

Keywords: Traditional gender beliefs, religion, Turkey.

Dr., Adıyaman Üniversitesi, Fen-Edebiyat Fakültesi, Sosyoloji Bölümü, ahmetfidan@adiyaman.edu.tr 


\title{
TÜRKIYE'DE DINI FAKTÖRLERIN GELENEKSEL CINSIYET INANÇLARINA ETKISi
}

\begin{abstract}
$\ddot{O} z$
Bu çalışmanın temel amacı, seküler ve Müslüman bir ülke olan Türkiye'de dindarlık ile toplumsal cinsiyet gelenekçiliği arasındaki ilişkiyi incelemektir. Önceki araştırmalara ve bakış açılarına dayanarak, test etmek için çeşitli hipotezler geliştirilmiştir. Analiz için Avrupa Değer Araştırması ve Dünya Değer Araştırması tarafından 2018 yılında Türkiye'den toplanan ortak bir veri kullanılmıştır. Her bir öngörücü değişkenin geleneksel cinsiyet inançları üzerindeki etkisini test etmek için bir dizi doğrusal lojistik regresyon modeli oluşturulmuştur. Sonuçlar, sübjektif dindarlığın ve dine verilen önemin, cinsiyet gelenekçiliği ile güçlü, anlamlı ve olumlu bir şekilde ilişkili olduğunu, ibadet etme pratiğinin ise cinsiyet gelenekçiliği üzerinde hafif ve olumlu bir etki gösterdiğini göstermiştir. Çalışmanın sonuçları tartışılmış, sonuçlandırılmış ve gelecekteki çalışmalar için sınırlamalar belirlenmiştir.
\end{abstract}

Anahtar Kelimeler: Geleneksel cinsiyet inançları, din, Türkiye.

\section{INTRODUCTION}

For several decades, social researchers have shown a hectic interest in traditional gender beliefs and attitudes in different societies. Traditional gender role beliefs have been considered as people's acceptance of social norms that give males more power than females in the social structure of society (Shearer et al., 2005). Patriarchy or traditional gender beliefs is defined as a comprehensive network or system of hierarchical structure that spans political, economic, social, religious, cultural, industrial, and financial domains, with men occupying or controlling and dominating the vast majority of top positions in society (Attoh, 2017). According to social scientists, men's and women's power disparities are deeply rooted in even modern social structures and generating and retaining traditional gender relations in society (Fidan \& Bui, 2016; Shearer et al., 2005; Walby, 1990). Even though the power balance is changing, 
particularly in the Western world, prevalent acceptance of this power structure remains based on gender roles (Pietromonaco et al., 2020). Beliefs and attitudes are important and may characterize a person's conception of the world about any social issue. For instance, people with more egalitarian gender attitudes are less likely to support patriarchy as a societal system, whereas those with more conventional gender attitudes are more likely to embrace the patriarchal system's precepts (Perales \& Bouma, 2019).

Although the relationship between demographic factors and gender traditionalism has been documented in previous research, there is still a scarcity of research that focuses on the effect of religious factors on gender traditionalism, particularly in developing or non-Western countries. Religion is an important cultural determinant that supplies a pretty consistent approach to organizing and prioritizing values, to the point where religiosity has been connected to specific values (Mikołajczak \& Pietrzak, 2014). Existing research mostly has been focused on the Western context and developed countries (Perales \& Bouma, 2019; Seguino, 2011). In that area, there is little research that has been done utilizing more current national samples and concentrating on distinct country contexts. Particularly, in Turkey, the research on the association between religious factors and gender traditionalism scarcely nonexist. Having a secular and religious society makes Turkey a substantial and interesting case to study the association between religious factors and social beliefs.

The main purpose of this study is to contribute to work up in the area of sociology of religion by examining the relationship between religious factors and traditional gender beliefs in a Muslim and secular country, Turkey. first, the present research documents previous research, which has examined the association between religion and gender traditionalism. Next, the study will 
reveal how Islamic doctrines work on traditional gender beliefs. Based on these doctrines, several hypotheses will be developed. Then, these hypotheses will be tested by data obtained from the 2018 jointly European Value Survey (EVS) and World Value Survey (WVS), the case of Turkey. The results will be presented by a series of models from linear logistic regression. Finally, implications will be discussed and concluded, limitations will be identified for future studies.

\subsection{Traditional Gender Beliefs in Turkey}

Turkish society is widely seen as patriarchal, with distinct gender roles, and, therefore, marriage and family are both can be considered notably patriarchal (Sakalli, 2001). In other words, girls and boys in Turkey are socialized with traditional sexist views. Gender roles are socialized in the household, and girls and boys learn diverse gender stereotypes from an early age (Sakalli, 2002). Girls are raised to be submissive and obedient in the home, whereas boys are taught to be more aggressive and independent (Oksal, 2007). As a result, men raised in patriarchal ideology realize women's reliance on them in interpersonal relations. Thus, after learning and accepting these gender ideologies, men maintain to impose those beliefs against women in marriage and society in Turkey. In this manner, men and women have different roles in marriage and family institutions. For example, in the family, men's roles are to be authoritative, head of the household, and to preserve the family structure, whereas women's roles are to care for members of the family and to run the house as caregivers.

Due to its Westernization and institutionalization efforts since its founding, contemporary Turkey cannot be compared to other Islamic countries (Arat, 2008). However, although Turkey's economy has improved since the beginning of the century, female empowerment has remained stagnant in every way (Engin \& Pals, 2018). A new study conducted by Engin and Pals (2018) indicated 
that Turkey has become more patriarchal since the 1990s. Furthermore, their study demonstrated that the influence of religion on patriarchal attitudes has waned through time, although the influence of political conservatism has stayed consistent in Turkey.

\subsection{Literature Review}

Many ideals are created in cultures that promote women's subordination to men. Religion plays a significant cultural role in the formation of values that promote women's inferiority to men (Sambur, 2021). Religion is an aspect of culture in the broadest sense, as well as the formation of society, and civilization without religion has never existed (Attoh, 2017). Every religion encourages slightly different standards, establishes distinct organizations, and rests on cultural and historical underpinnings (Klingorova \& Havlicek, 2015). Personal world religions possess varying degrees of effect on women's status in societies.

According to Ozorak (1996) involvement of women in religion is a paradox. Because women of all ages are more religious than men. In other words, women are more likely than men to identify as religious, to attend religious services, pray regularly, feel close to God, and give more importance to their religious services (Ozorak, 1996). Organized religious organizations, which create cultural norms, social regulations, and behaviors, have a substantial effect on the strictness of gender roles and attitudes, according to a large body of data (Inglehart \& Norris, 2003). Even though women identify themselves as more religious, they may get less benefit from the teachings of their religion.

Several studies, in modern countries, have well-documented the relationship between religion and traditional gender beliefs and attitudes. For instance, a study conducted by Acevedo and Shah (2015) purposed and investigated the 
effect of Sunni-Shi'a affiliation on views of gender traditionalism. In their study, the authors used large data from the World Value Survey of four important Muslim countries: Iran, Iraq, Lebanon, and Pakistan. Their findings exhibited that, rather than sectarian affiliation alone, educational achievement, income, demographic characteristics, and national culture are stronger and more consistent determinants of gender traditionalism. In addition, their study indicated that as a religious factor, the importance of religion was significantly related to gender traditionalism. In other saying, people who give more importance to their religion hold more traditional gender beliefs in Muslim countries.

A study conducted by Klingorova and Hevlicek (2015) tried to examine the influence of religions on the status of women and the state of gender inequality by using a sample of 50 countries worldwide. Their findings revealed that first, countries, where the majority of respondents are without religious affiliations, exhibit the lowest levels of gender inequality. Second, Christian and Buddhist countries or societies have average levels of gender inequality. Finally, countries with the greatest levels of gender inequality across the observed variables, whose participants adhere to Islam and Hinduism. Based on their results, the authors suggested that the association between religion and gender traditionalism can be clarified by that those societies that possess a greater level of religiosity usually approve the authority of religious scholars who have a substantial influence on society to hold patriarchal beliefs and attitudes (Klingorova \& Hevlicek, 2015).

Another study carried out by Goldscheider and colleagues (2014) tried to examine the relationship between religiosity and several measures of attitudes and behaviors related to gender disparity in the public and private spheres in Sweden. They used two waves of data from the Swedish Adult Panel Survey of 
1999 and 2003. Their findings revealed that higher religiosity is associated with more patriarchal beliefs about the balance of roles of men and women in the household.

\subsection{Hypotheses}

Based on the literature reviewed above, the present research developed three hypotheses that will test the effect of religion on traditional gender beliefs:

H1: Self-identification as "religious" will be more likely to associated with a higher level of traditional gender beliefs in Turkey

$\mathrm{H}$ 2: Higher given importance to religion will be associated with a higher level of traditional gender beliefs in Turkey

H3: Greater prayer practice among people will be associated with a higher level of traditional gender beliefs in Turkey

\section{METHOD}

\subsection{Data and Sample}

Data from the present study was obtained from the 2017-2020 jointly European Value Survey (EVS) and World Value Survey (EVS) the case of Turkey (2018), which was conducted from March 2018 through May 2018 (EVS, 2020; WVS, 2020). The EVS and the WVS are two large-scale, cross-national, and longitudinal surveys. They include many questions about respondents' attitudes, behaviors, religious affiliations, preferences, values, and opinions from worldwide. The wave of 2018 jointly EVS and WVS of Turkey include 2,415 cases. After the elimination of cases of dependent and independent variables, a subsample of $1,974 \mathrm{~s}$-cases was created for data analysis of the present study. 


\subsection{Variables}

\section{Dependent Variables}

Traditional gender beliefs: The EVS and WVS include some items aimed to measure the valuation of traditional gender beliefs. This variable was constructed from responses to three questions relevant conditions under which respondents believe gender beliefs are supported: a) men make better political leaders than women do, b) university is more important for a boy than for a girl, and c) men make better business executives than women. These three questions have categorical responses and recoded as from 1 = strongly disagree to 4 = strongly agree. An index variable was created to represent whether respondents support these traditional gender beliefs. The three-item index was found to be fairly reliable (Cronbach's alpha $=.75$ )

\section{Independent Variables}

Three independent variables were included in the data analysis as religious factors related to traditional gender beliefs. The first independent variable is subjective religiosity, which is measured by a question that asks "Independently of whether you go to religious services or not, would you say you are a religious person, not a religious person, or a convinced atheist?" Because of a small portion of convicted atheists in the sample, the category of convicted atheists was added to the non-religious category. Therefore, a binary variable was created with $0=$ non-religious person (reference category) and $1=$ religious person.

Second, given importance to religion is a Likert-type scale item, which inquires the individuals with a question: "For each of the following aspects, how important it is in your life: religion" Responses were recoded as a greater 
number exhibiting higher importance is given to religion ( $1=$ not at all important, 2 = not very important, 3 = rather important, 4 = very important).

The third independent variable displays the frequency of prayer practice among respondents. The WVS asks respondents that, "Apart from religious services, how often do you pray?" The item was recoded on an eight-point scale that higher number indicating a greater level of prayer practice (from 1 = never, practically never, to $8=$ several times a day).

\section{Control Variables}

Based on the literature, many statistical control variables were included in the data analysis. Respondents' age was a continuous variable from 18 to 82 years old. Gender is a dichotomous variable with $0=$ female (reference category) and $1=$ male. The number of children is a continuous variable reflecting how many children a respondent has. Marital status was recoded as a categorical variable with $0=$ single/never married (reference category), $1=$ married, and $2=$ other (divorced, widowed etc.). Educational level is an index variable from $1=$ less than primary education to $8=$ doctoral or equivalent. Finally, income level is a scale variable from $1=$ lower step to $10=$ tenth step.

\section{RESULTS}

\subsection{Sample Characteristics}

Table 1. demonstrates the demographic characteristic of respondents from Turkey. According to the results, the age of respondents in the sample ranged from $18-82$ years, with a mean of 39.16 years $(S E=0.28)$. Males and females respondents have the same number. The mean number of children was 1.36 from 0 to 5 and over (SE $=0.03$ ). The majority of the respondents were married (63.4\%) while $31 \%$ of those were single. The mean of education was 4.05 on a 9- 
point scale $(S E=0.05)$ and the mean of income was 5.35 on a 10-point scale (SE $=0.04)$. Most of the respondents identified themselves as religious (72.7\%). However, the frequency of non-religious people (27.3\%) was high in a country that is known as a highly religious society. The mean level of importance given to religion was 3.45 on a scale of 4 -point $(S E=0.01)$. The mean level of prayer practice was 6.37 on an 8-point scale $(S E=0.04)$. Regarding the dependent variable, the mean level of traditional gender beliefs was 7.12 on a scale from 3 to $12(\mathrm{SE}=0.04)$.

Table 1. Descriptive Statistics ( $N=1,974)$

\begin{tabular}{lrrrr}
\hline Variables & $\boldsymbol{n}$ & percentage & Min. & Max. \\
\hline Female & 987 & $50.0 \%$ & & \\
Male & 987 & $50.0 \%$ & & \\
Single & 617 & $31.3 \%$ & & \\
Married & 1,251 & $63.4 \%$ & & \\
Other & 106 & $5.4 \%$ & & \\
Non-religious & 539 & $27.3 \%$ & & \\
Religious & 1,435 & $72.7 \%$ & & \\
\hline & $\boldsymbol{M}$ & $\boldsymbol{S . E}$ & Min. & \\
\hline Age & 39.16 & 0.28 & 18 & 82 \\
Children & 1.36 & 0.03 & 0 & 5 \\
Education & 4.05 & 0.05 & 0 & 8 \\
Income & 5.35 & 0.04 & 1 & 10 \\
Importance of religion & 3.45 & 0.01 & 1 & 4 \\
Prayer & 6.37 & 0.04 & 1 & 8 \\
Traditional gender beliefs & 7.12 & 0.04 & 3 & 12 \\
\hline
\end{tabular}

\subsection{Multivariate Analysis}

The present study, below, using weighted data, estimates linear logistic regressions and reckons the influence of religious determinants and related factors on traditional gender beliefs in Turkey. Five model analyses of nested modeling were conducted to test each of the hypotheses and were used to designate the effects of religious determinants on traditional gender beliefs independently from the effects of demographic variables. The first model 
(Model 1) included only control variables to reveal their effects on the dependent variable. Next, Model 2 (self-religiosity), Model 3 (importance of religion), and Model 4 (prayer practice) indicate the effects of each religious dimension on the dependent variable while controlling variables were controlled. Finally, Model 5 includes all variables to assess each religious factor's sole effect on traditional gender beliefs independently from the effects of other variables in the models.

Table 2 indicates that, in Model 1, being a male and being married were significantly and positively associated with traditional gender beliefs. The mean level of traditional gender beliefs is .765 higher for male respondents than for female respondents $(b=.765, t=8.01, p<.001)$. The mean level of traditional gender beliefs is .403 higher for married respondents than single respondents $(b=.403, t=2.77, p<.01)$. On the contrary, educational level and income level were significantly and negatively associated with traditional gender beliefs. For one unit increase in educational level, the expected traditional gender beliefs decrease by a factor of $.086(b=-.086, t=-4.11, p<.001)$. For one unit increase in income level, the expected traditional gender beliefs decrease by .081 ( $b=$ $.081, \mathrm{t}=-2.81, \mathrm{p}<.01)$.

Model 2 shows that self-identification of religiosity was highly significantly and positively related to traditional gender beliefs. In other words, holding all other variables constant, the mean level of traditional gender beliefs is .541 higher for religious respondents than non-religious respondents $(b=.541, t=5.09, p<$ .001). Model 2 exhibits the importance of religion was fairly significantly and positively associated with traditional gender beliefs. All else being equal, one unit increase in given importance to religion, the expected traditional gender beliefs increases by .466 units $(b=.466, t=7.19, p<.001)$. Model 4 displays that prayer practice was slightly and positively linked to traditional gender 
beliefs. Holding all other variables constant, one unit increase in the practice of prayer, the expected traditional gender beliefs increases by a factor of .047 ( $b=$ $.047, \mathrm{t}=1.87, \mathrm{p}<.10)$.

Table 2. Linear Logistic Regression: Parameter Estimates For Traditional Gender Beliefs

\begin{tabular}{|c|c|c|c|c|c|}
\hline Variables & $\begin{array}{l}\text { Model } 1 \\
\mathrm{~B}(\mathrm{SE})\end{array}$ & $\begin{array}{l}\text { Model } 2 \\
\mathrm{~B}(\mathrm{SE})\end{array}$ & $\begin{array}{l}\text { Model } 3 \\
\mathrm{~B}(\mathrm{SE})\end{array}$ & $\begin{array}{l}\text { Model } 4 \\
\mathrm{~B}(\mathrm{SE})\end{array}$ & $\begin{array}{l}\text { Model } 5 \\
\mathrm{~B}(\mathrm{SE})\end{array}$ \\
\hline Age & $\begin{array}{l}-.007 \\
(.005)\end{array}$ & $\begin{array}{l}-.006 \\
(.005)\end{array}$ & $\begin{array}{l}.005 \\
(.005)\end{array}$ & $\begin{array}{l}.006 \\
(.005)\end{array}$ & $\begin{array}{l}-.005 \\
(.005)\end{array}$ \\
\hline Male & $\begin{array}{l}.765^{* * *} \\
(.09)\end{array}$ & $\begin{array}{l}.751^{* * *} \\
(.09)\end{array}$ & $\begin{array}{l}.740 * * * \\
(.09)\end{array}$ & $\begin{array}{l}.764^{* * *} \\
(.09)\end{array}$ & $\begin{array}{l}.735^{* * *} \\
(.09)\end{array}$ \\
\hline Children & $\begin{array}{l}.039 \\
(.04)\end{array}$ & $\begin{array}{l}.033 \\
(.04)\end{array}$ & $\begin{array}{l}.002 \\
(.04)\end{array}$ & $\begin{array}{l}.027 \\
(.04)\end{array}$ & $\begin{array}{l}.003 \\
(.04)\end{array}$ \\
\hline Married & $\begin{array}{l}.403^{* *} \\
(.14)\end{array}$ & $\begin{array}{l}.340^{*} \\
(.14)\end{array}$ & $\begin{array}{l}.347^{*} \\
(.14)\end{array}$ & $\begin{array}{l}.397^{* *} \\
(.14)\end{array}$ & $\begin{array}{l}.317^{*} \\
(.14)\end{array}$ \\
\hline Other & $\begin{array}{l}.085 \\
(.24)\end{array}$ & $\begin{array}{l}.076 \\
(.24)\end{array}$ & $\begin{array}{l}.089 \\
(.24)\end{array}$ & $\begin{array}{l}.069 \\
(.24)\end{array}$ & $\begin{array}{l}.082 \\
(.24)\end{array}$ \\
\hline Education & $\begin{array}{l}-.086 * * * \\
(.04)\end{array}$ & $\begin{array}{l}-.078^{* * *} \\
(.02)\end{array}$ & $\begin{array}{l}-.075^{* * *} \\
(.02)\end{array}$ & $\begin{array}{l}-.084^{* * *} \\
(.02)\end{array}$ & $\begin{array}{l}-.072^{* *} \\
(.02)\end{array}$ \\
\hline Income & $\begin{array}{l}-.081^{* *} \\
(.02)\end{array}$ & $\begin{array}{l}-.080^{* *} \\
(.03)\end{array}$ & $\begin{array}{l}-.087^{* *} \\
(.02)\end{array}$ & $\begin{array}{l}-.081^{* *} \\
(.02)\end{array}$ & $\begin{array}{l}-.086^{* *} \\
(.02)\end{array}$ \\
\hline Religious & & $\begin{array}{l}.541^{* * *} \\
(.10)\end{array}$ & & & $\begin{array}{l}.322^{* *} \\
(.11)\end{array}$ \\
\hline Imp. of Relig. & & & $\begin{array}{l}.466 * * * \\
(.06)\end{array}$ & & $\begin{array}{l}.398^{* * *} \\
(.06)\end{array}$ \\
\hline Prayer & & & & $\begin{array}{l}.047 \dagger \\
(.02)\end{array}$ & $\begin{array}{l}.004 \\
(.02)\end{array}$ \\
\hline$F$ & $16.505^{* * *}$ & $17.875^{* * *}$ & $21.277^{* * *}$ & $14.900 * * *$ & $17.922^{* * *}$ \\
\hline Adjusted $\mathrm{R}^{2}$ & .052 & .064 & .076 & .053 & .079 \\
\hline $\mathrm{N}$ & 1,974 & 1,974 & 1,974 & 1,974 & 1,974 \\
\hline
\end{tabular}

Finally, Model 5 (full model) reveals that, among religious factors, self-religiosity $(b=.322, t=2.85, p<.01)$ and the importance of religion $(b=.398, t=5.75, p<$ .001) remain significant while prayer practice loses its slight significance. In other words, prayer practice's slight effect disappears after other religious factors were added to the model. Therefore, it is possible to state that the findings tend to demonstrate that prayer practice has a moderate effect on 
traditional gender beliefs. Based on these results, regarding traditional gender beliefs, hypothesis 1 and hypothesis 2 are supported while hypothesis 3 is partially supported by analysis of the data.

\section{DISCUSSION AND CONCLUSION}

The current research adds to the previous studies on traditional gender beliefs and attitudes and improves literature by focusing on a Muslim and secular country. The present study aimed to examine the association between religious dimensions and public traditional gender beliefs in Turkey. This research, as known, is the first work to focus on this relationship systematically. Even in the Western context, there is a scarcity of research on this relationship. Therefore, this study included three important factors of religiosity to view the effect of religion on gender traditionalism. In general, the findings of the study showed up two religious dimensions as strong and significant determinants of traditional gender beliefs in Turkey. Before the move to discuss this relationship, it is important to state that descriptive statistics of the study indicated that the frequency of religiosity and hilding traditional or patriarchal gender beliefs are still high in Turkey.

First, subjective religiosity has been viewed as one of the important religious factors in the previous studies that have worked on the sociology of religion (Chatters et al., 2008; Ellison et al., 2015; Hudson et al., 2015; Taylor et al., 1999). Based on literatüre, this study included subjective religiosity as an indicator of religiosity. Findings of the study indicated that people who identified themselves as religious were more likely to hold traditional gender beliefs than non-religious individuals. This result supported the first hypothesis (H1) of the current research, which predicted that religious people would have a higher level of traditional gender beliefs than non-religious people. Based on 
this finding, it is possible to state that personal religiosity remains an important factor that can influence any social issue in a Muslim and secular society.

Second, in previous studies, religious salience also has been considered as a substantial factor of religiosity. Therefore, the current study hypothesized $(\mathrm{H} 2)$ that higher given importance to religion would be associated with a higher level of traditional gender beliefs in Turkey. The findings of the study showed strong support for this hypothesis. In other words, people who give more importance to their religion were more likely to hold traditional gender beliefs. These findings also are consistent with previous studies that work in this relationship (Acevedo \& Shah, 2015; Perales \& Bouma, 2019). Finally, prayer practice did not demonstrate a strong relationship with gender traditionalism. However, even with its lower significance on traditional gender beliefs, that factor still can be considered as an essential indicator of religiosity among Muslims. Overall, based on these findings, gender disparity at home and work is rooted in traditional patriarchal ideas and attitudes. The data of the current research suggests that religion in Turkey is still an important predictor of gender traditionalism. Because since the past to the present religion has been an important cultural function in the production of values that advocate women to be inferior to men in that country (Sambur, 2021). The existence and reality of a gender disparity in Turkish society cannot be segregated from the patriarchal and religious culture.

Before mentioning the limitations of the study, aside from religious factors, it is essential to address the role of the deömographic characteristics on traditional gender beliefs. First, the findings of the study showed that men and married individuals hold more patriarchal gender beliefs compared to women and nonmarried counterparts. On the contrary, educational level and income level are negative predictors of these beliefs in Turkey. These results are coherent with 
earlier research (Kane, 1995; Perales \& Bouma, 2019). It is possible to state that, based on these findings, increasing educational level and income will open a new avenue for people about these traditional beliefs. Therefore, more educational implementations and programs should fulfill by the governmental and non-governmental organizations to change people's thoughts, beliefs, and attitudes that give women secondary roles in families and society.

The current research has several limitations. First, it is important to note that data provided jointly by EVS and WVS is cross-sectional data. Even though the data analysis displays religious factors linked to traditional gender beliefs, there no existence of causality. In other words, as with other previous research, our findings point to significant patterns based on the data provided, but they fall short of establishing clear causal linkages. Second, data is limited by the number of questions or variables to grab perspectives on traditional gender roles. In the same way, the number of religious variables used to quantify qualities unique to Islam is limited. For example, questions about the five pillars of Islam, fasting, namaz, etc., are not available in the data. Finally, as many Muslim countries, including Turkey, have many different ethnicities, it would be better to have some items about individuals' ethnic disparities.

Although the present study acknowledges the limitations, the findings given by data analysis provide a valuable viewpoint on religious affiliation research. This research found that religious individuals hold more patriarchal beliefs that put women in a subordinate position in families and society. Whereas the findings are not as one-sided as our theories suggest, we view this research as a valuable addition to the scarce scientific literature on Muslim society. Moreover, the findings of our research imply that future theoretical frameworks examining the effect of religion Islamic society should take into consideration external factors 
that interact with religious elements to shape behavioral and attitudinal results in mostly Muslim nations.

\section{REFERENCES}

Acevedo, G. A., Ellison, C. G., \& Yilmaz, M. (2015). Religion and child-rearing values in Turkey. Journal of Family Issues, 36(12), 1595-1623.

Acevedo, G.A., \& Shah, S. (2015). Sectarian affiliation and gender traditionalism. Sociology of Islam, 3, 1-29.

Arat, Y. (2008). Religion, politics and gender equality in Turkey: implications of a democratic paradox? Third World Quarterly, 31(6), 869-884.

Attoh, F. (2017). Gender, religion and patriarchy: A sociological analysis of Catholicism And Pentecostalism In Nigeria. Advances in Social Sciences Research Journal, 4(14) 158-170.

Chatters, L. M., Taylor, R. J., Bullard, K. M., \& Jackson, J. S. (2008). Spirituality and subjective religiosity among African Americans, Caribbean blacks, and non-Hispanic whites. Journal for the Scientific Study of Religion, 47(4), 725-737.

Engin, C., \& Pals, C. (2018). Patriarchal attitudes in Turkey 1990-2011: The influence of religion and political conservatism. Social Politics: International Studies in Gender, State and Society, 25, 383 - 409.

EVS (2020). European Values Study 2017: Integrated Dataset (EVS 2017). GESIS Data Archive, Cologne. ZA7500 Data file Version 4.0.0, doi:10.4232/1.13560.

Fidan, A., \& Bui, H. N. (2016). Intimate Partner Violence Against Women in Zimbabwe. Violence Against Women, 22(9), 1075-1096.

Goldscheider, F., Goldscheider, C., \& Rico-Gonzalez, A. (2014). Gender Equality in Sweden: Are the Religious More Patriarchal? Journal of Family Issues, 35(7), 892-908. 
Hudson, D. L., Purnell, J. Q., Duncan, A. E., \& Baker, E. (2015). Subjective religiosity, church attendance, and depression in the National Survey of American Life. Journal of religion and health, 54(2), 584-597.

Inglehart, R., \& Norris, P. (2003). Rising tide: Gender equality and cultural change around the world. Cambridge, UK: Cambridge University Press.

Kane, E. (1995). Education and beliefs about gender inequality. Social Problems, 42, 74-90.

Klingorová, K. \& Havlíček, T. (2015). Religion and gender inequality: The status of women in the societies of world religions. Moravian Geographical Reports,23(2) 2-11.

Mikołajczak, M. and Pietrzak J. (2014). Ambivalent sexism and religion: Connected through values. Sex Roles, 70(9-10), 387-99.

Oksal, A. (2008). Turkish family members' attitudes toward Lesbians and gay men. Sex Roles, 58, 514-525.

Ozorak, E. W. (1996). The power, but not the glory: How women empower themselves through religion. Journal for the Scientific Study of Religion, 35(1), 17-29.

Perales, F., \& Bouma, G. (2019). Religion, religiosity and patriarchal gender beliefs: Understanding the Australian experience. Journal of Sociology, 55(2), 323-341.

Pietromonaco, P. R., Overall, N. C., Beck, L. A., \& Powers, S. I. (2020). Is low power associated with submission during marital conflict? Moderating roles of gender and traditional gender role beliefs. Social Psychological and Personality Science, 12(2), 165-175.

Sakalli N. (2001). Beliefs about wife beating among Turkish college students:

The effects of patriarchy, sexism, and sex differences. Sex Roles, 44(9/10), 599-610.

Sakalli, N. (2002). The relationship between sexism and attitudes toward 
homosexuality in a sample of Turkish college students. Journal of Homosexuality, 42(3), 53-64.

Sambur, B. (2021). Din ve ataerkil kıskacında kadın. Retrieved from:

https://turkish.aawsat.com/home/article/2904681/profdr-bilalsambur/din-ve-ataerkil-k\%C4\%B1skac\%C4\%B1nda-kad\%C4\%B1n

Shearer, C. L., Hosterman, S. J., Gillen, M. M., \& Lefkowitz, E. S. (2005). Are traditional gender role attitudes associated with risky sexual behavior and condom-related beliefs? Sex Roles, 52(5-6), 311-324.

Taylor, R. J., Mattis, J., \& Chatters, L. M. (1999). Subjective religiosity among African Americans: A synthesis of findings from five national samples. Journal of Black Psychology, 25(4), 524-543.

WVS (2020). Haerpfer, C., Inglehart, R., Moreno, A., Welzel, C., Kizilova, K., DiezMedrano J., M. Lagos, P. Norris, E. Ponarin \& B. Puranen et al. (eds.). 2020. World Values Survey: Round Seven-Country-Pooled Datafile. Madrid, Spain \& Vienna, Austria: JD Systems Institute \& WVSA Secretariat. Version 1.0.5, doi:10.14281/18241.1.

Walby, S. (1990). Theorizing Patriarchy. Oxford: Blackwell. 


\section{GENIŞLETILMiş ÖZET}

\section{Giriş}

On yıllar boyunca, sosyal araştırmacılar farklı toplumlardaki geleneksel cinsiyet inançlarına ve tutumlarına yoğun bir ilgi göstermişlerdir. Geleneksel cinsiyet rolü inançları, toplumun sosyal yapısında erkeklere kadınlardan daha fazla güç veren sosyal normların insanların kabulü olarak değerlendirilmiştir. Sosyal bilimcilere göre, erkek ve kadınların güç eşitsizlikleri, modern sosyal yapılarda bile derinden kök salmakta ve toplumda geleneksel cinsiyet ilişkilerini oluşturup muhafaza etmektedir. Güç dengesi, özellikle Batı dünyasında değişse de, bu güç yapısının yaygın kabulü, cinsiyet rollerine dayalı olmaya devam etmektedir. Bu açıdan inançlar ve tutumlar tarih boyunca bireyler üzerinde önemli bir yer tutmuş ve bir kişinin herhangi bir sosyal konu hakkındaki dünya görüşünü karakterize edebilirler. Örneğin, daha eşitlikçi cinsiyet tutumlarına sahip kişilerin toplumsal bir sistem olarak ataerkilliği destekleme olasılığı daha düşükken, daha geleneksel cinsiyet tutumlarına sahip olanların ataerkil sistemin kurallarını benimseme olasılığı daha yüksektir.

Demografik faktörler ve toplumsal cinsiyet gelenekçiliği arasındaki ilişki önceki araştırmalarda belgelenmiş olsa da, özellikle gelişmekte olan veya Batılı olmayan ülkelerde dini faktörlerin toplumsal cinsiyet gelenekçiliği üzerindeki etkisine odaklanan araştırma kıtlığı hala mevcuttur. Din, değerleri organize etme ve önceliklendirme konusunda oldukça tutarlı bir yaklaşım sağlayan önemli bir kültürel belirleyicidir, öyle ki dindarlık belirli değerlerle bağlantılıdır. Mevcut araştırmalar çoğunlukla Batı bağlamına ve gelişmiş ülkelere odaklanmıştır. Bu alanda, daha güncel ulusal örnekleri kullanan ve farklı ülke bağlamlarına odaklanan çok az araştırma var. Özellikle Türkiye'de dini faktörler ile toplumsal cinsiyet gelenekçiliği arasındaki ilişkiye yönelik araştırmalar yok denecek kadar azdır. Laik ve dindar bir topluma sahip olmak, Türkiye'yi bu anlamda dini faktörler ve sosyal inançlar arasındaki ilişkiyi incelemek için önemli ve ilginç bir örnek haline getirmektedir. Bu yüzden bu çalışmanın amacı Türkiye'de dini faktörlerin toplumsal cinsiyet inançları veya tutumları üzerindeki etkisini incelemektedir.

\section{Yöntem}

Bu çalışmadan elde edilen veriler, Mart 2018'den Mayıs 2018' e kadar olan aralıkta toplanan, 2017-2020 yılları arasında ortaklaşa yürütülen Avrupa Değer Araştırması (ADA) ve Dünya Değer Araştırması (DDA) Türkiye örneğinden (2018) elde edilmiştir. ADA ve DDA iki büyük ölçekli, uluslar arası ve boylamsal anketlerdir. Katılımcıların tutumları, davranışları, dini bağlantıları, tercihleri, değerleri ve dünya çapındaki görüşleri hakkında birçok soru içermektedir. 
Türkiye'nin ADA ve DDA'nin ortaklaşa yaptığı 2018 yılı çalışması 2.415 katılımcıyı içermektedir. Bağımlı ve bağımsız değişkenlerin içerisinde yer alan eksik değerlerin elimine edilmesinden sonra, bu çalışmanın veri analizi için 1.974 kişilik bir alt örneklem oluşturulmuştur.

Çalışmanın bağımlı değişkeni olarak toplumsal cinsiyet inançlarının belirlendiği üç soru bir araya getirilerek oluşturulmuştur. Bağımsız değişkenleri ise, üç adet dini faktörden oluşmaktadır: kişisel dindarlık, dine verilen önem ve ibadet etme. Çalışmanın kontrol değişkenleri ise altı adet demografik karakterlerden oluşmaktadır: yaş, cinsiyet, medeni durum, çocuk sayısı, eğitim seviyesi ve gelir durumu.

\section{Bulgular}

Ağırlıklı verileri kullanan bu çalışma, doğrusal lojistik regresyonları tahmin etmekte ve dini belirleyicilerin ve ilgili faktörlerin Türkiye'deki geleneksel cinsiyet inançları üzerindeki etkisini hesaplamıştır. Hipotezlerin her birini test etmek için iç içe modellemenin beş model analizi yapılmış ve dini belirleyicilerin geleneksel cinsiyet inançları üzerindeki etkilerini demografik değişkenlerin etkilerinden bağımsız olarak belirlemek için kullanılmıştır. Çalışmanın bulgularına göre, kişisel dindarlık açısından bakıldığında, kendini dindar olarak gören kişiler dindar olmayan kişilere göre toplumsal cinsiyetçi rolleri daha çok benimsemektedir. Başka bir deyişle, kişisel dindarlık ve toplumsal cinsiyetçi inançları destekleme arasında pozitif bir ilişki bulunmaktadır. Yine buna benzer olarak, dine verilen önem de toplumsal cinsiyet rollerine verilen desteği artırmaktadır. Başka bir deyişle, bütün kontrol değişkenleri kontrol edildiğinde, dine verilen önem arttıkça, toplumsal cinsiyet gelenekçiliği de artmaktadır. Çalışmanın p değeri (anlamlıık) açısından bakıldığında, bu iki dini faktör ile toplumsal cinsiyetçiliği destekleme arasında çok güçlü ilişki bulunmaktadır. Bununla beraber, sosyal dindarlığın önemli göstergelerinden olan ibadet etme sıklığı ile toplumsal cinsiyet inançları arasında hafif denilebilecek bir ilişki bulunmuştur. Burada da kişiler arasında ibadet etme sıklığı arttıkça toplumsal cinsiyet değerlerini destekleme artmaktadır. Çalışmanın regresyon analizindeki tam modeline göre ibadet etme sıklığı diğer dini değişkeler ile geleneksel cinsiyet rolleri arasında aracılık görevi görmektedir.

Bu önemli bulgulara ek olarak, demografik özelliklerin de geleneksel cinsiyet inançları üzerindeki etkilerine değinmekte fayda görülmüştür. Çalışmanın bulgularına göre, erkek olma ve evli olma toplumsal cinsiyetçi inançlar üzerinde pozitif bir etkide bulunurken, eğitim seviyesini ve gelir durumunun yükselmesi ise bu rollere verilen desteği azaltmaktadır. 


\section{Tartışma ve Sonuç}

Bu çalışmanın ana amacı, Türkiye'de önceki dönemlerde görmezden gelinmiş olan dini faktörlerin geleneksel cinsiyet rolleri üzerindeki etkisini sistematik bir şekilde incelemekti. Çalışmanın bulgularına göre, dini faktörler veya dindarlığın geleneksel cinsiyet rolleri üzerine pozitif bir etkide bulunmaktadır. Çalışmanın bulguları daha önce yapılmış olan çalışmalarla uyumlu sonuçlar göstermiştir. Bundan dolayı şunu belirtmekte fayda vardır: her ne kadar ayrı kültür ve dini değerlere sahip olunsa bile, bu dini değerler toplumsal sorunlar, inançlar, davranışlar ve tutumlar üzerinde aynı etkiyi gösterebilmektedir. Bundan dolayı ileride yapılacak çalışmalarda ayrı dini değer ve kültürlere sahip olan ülkeler arasında bu alanda karşılaştırmalı çalışmalar yapmakta fayda görülmektedir. 